\title{
In memoriam Dr. Seiji Yamagami
}

A restless spirit. A man challenged by novel ideas and dreams, unselfishly seeking to improve the lives of individuals and communities alike. A very private man, yet no one was a stranger to him. Seiji Yamagami was all of these, an enigma. July 7, 1999, marked the first anniversary of his death. He left many things unfinished, but his efforts and his accomplishments are continuing to be realized and implemented. Dr. Yamagami's work continues to influence those who knew him well and also those whom he helped through his determination to provide better health care.

In 1995 and 1996, two dramatic and devastating events struck the Kansai area: the Hanshin Earthquake and the Escherichia coli O-157 epidemic. After the earthquake, Dr. Yamagami played a dynamic leadership role in both organizing and taking part in relief activities involving the evacuation of victims and providing hemodialysis and trauma care for them. He also focused on supplying accurate post-earthquake information and essential medical services through the Internet.

When the E. coli O-157 epidemic hit Japan, Dr. Yamagami utilized his experience to develop a highly effective program for physician access via the Internet, thus significantly reducing the mortality rate.

Dr. Yamagami became very interested in the prospects of education using the Internet for both the public at large and university medical students. He developed a successful Open University Program that attracted many participants in the Osaka area and nationwide.

\begin{tabular}{ll}
\hline KARGER & @ 2000 S. Karger AG, Basel \\
Fax +4161306 1234 & 0253-5068/00/0181-0060\$17.50/0 \\
$\begin{array}{l}\text { E-Mail karger@karger.ch } \\
\text { www.karger.com }\end{array}$ & $\begin{array}{l}\text { Accessible online at: } \\
\text { www.karger.com/journals/bpu }\end{array}$
\end{tabular}

Dr. Yamagami was also a prolific writer, and he worked to make inroads into the field of medical economics, publishing Medical Economics Problems in Dialysis Treatment for Chronic Renal Failure in Japan in 1995. His second book was Medical Economy of Home Care in Japan (1997). His third text, Medical Economy of Kidney Transplantion, is now being completed by the researchers who were collaborating with him.

He worked closely with younger doctors in the department, providing opportunities and support for their reseach in blood purification and problems in bacterial contamination of dialysate. He was a Charter Member of the International Society of Blood Purification where he encouraged active membership and participation by Japanese physicians. He worked closely with colleagues to bring hemofiltration to chronic renal failure patients in Japan and to improve its quality.

Dr. Yamagami was a unique, retiring, and complex person who sought change, and made many changes in what he believed was necessary and beneficial to society. His energy and curiosity led him to new ideas and methods. His dynamic spirit will continue to be an essential part of the medical and academic programs at Osaka City University Medical School.

Taketoshi Kishimoto

Hilah Edney

Osaka City University

Medical School
Prof. Taketoshi Kishimoto

Department of Urology, Osaka City University Medical School

1-5-7, Asahi-Machi, Abeno-ku

545 Osaka (Japan)

Tel. +8166452166, Fax +8166474426 